\title{
Excessive Weight Gain during Pregnancy and Prognosis of Childbirth in Douala (Cameroun)
}

\section{Henri Essome1,2, Valere Mve Koh ${ }^{3,4}$, Michel Ekono',3, Merlin Boten1, Jean Paul Engbang1,2*, Matio Bewekedi2, Pascal Foumane ${ }^{4,5}$}

${ }^{1}$ Douala Laquintinie Hospital, Douala, Cameroon

${ }^{2}$ Faculty of Medicine and Pharmaceutical Sciences, University of Douala, Douala, Cameroon

${ }^{3}$ University Hospital Center of Yaoundé, Yaoundé, Cameroon

${ }^{4}$ Faculty of Medicine and Biomedical Sciences, University of Yaoundé 1, Yaoundé, Cameroon

${ }^{5}$ Gyneco-Obstetrics and Pediatric Hospital of Yaoundé, Yaoundé, Cameroon

Email: *jean_pen@yahoo.ca

How to cite this paper: Essome, H., Mve Koh, V., Ekono, M., Boten, M., Engbang, J.P., Bewekedi, M. and Foumane, P. (2019) Excessive Weight Gain during Pregnancy and Prognosis of Childbirth in Douala (Cameroun). Open Journal of Obstetrics and Gynecology, 9, 242-250.

https://doi.org/10.4236/ojog.2019.92025

Received: December 3, 2018

Accepted: February 18, 2019

Published: February 21, 2019

Copyright () 2019 by author(s) and Scientific Research Publishing Inc. This work is licensed under the Creative Commons Attribution International License (CC BY 4.0).

http://creativecommons.org/licenses/by/4.0/

\begin{abstract}
The objective was to describe the maternofetal outcome of childbirth in women with excessive weight gain during pregnancy. We conducted a cross-sectional analytical study over a period of 03 months in the Obstetrics Department of Laquintinie Hospital in Douala (HLD). Our study population consisted of any pregnant in labor or waiting for a caesarean section. We compared two groups of pregnant women with excessive weight gain during pregnancy (exposed) and those without excessive weight gain during pregnancy (unexposed). We recorded 240 pregnant women who gave birth at the HLD maternity, 59 of whom had excessive weight gain during pregnancy, which gave us a proportion of $24.6 \%$. The only sociodemographic characteristic associated with excessive weight gain during pregnancy was the married marital status of the pregnant women (OR: $2.0(1.1-3.8) \mathrm{P}=0.023)$. Pregnant women with maternal complications associated with excessive weight gain had an average elevated uterine height of $35.4(\mathrm{P}=0.007)$. The increase in caesarean section rate $(\mathrm{P}=0.094)$ and the onset of pregnancy-related hypertension (HTA) showed differences close to significance $(\mathrm{P}=0.063)$. Mean birth weight was higher $(\mathrm{P}=0.023)$ in pregnant women with excessive weight gain during pregnancy. Ultimately, excessive weight gain during pregnancy has deleterious effects on the course of pregnancy and childbirth. It promotes the onset of pregnancy HTA and macrosomia.
\end{abstract}




\section{Keywords}

Excessive Weight Gain, Pregnancy, Maternofoetal Outcome

\section{Introduction}

Pregnancy is the essential and natural process by which the survival of a species is ensured. Because of its importance, pregnancy deserves special attention and must be accompanied by all the necessary measures to ensure that the future mother and the fetus have a healthy outcome at the end of this phenomenon [1] [2]. Maternal nutritional status before and during pregnancy exerts a considerable influence on fetal development and its fate at birth [3]. Weight gain during pregnancy is a physiological event; it is linked on one hand to the growth of fetal tissues and maternal metabolic changes with buildup of adipose tissue. Excessive weight gain during pregnancy has become a major public health problem globally; in addition to the cardiovascular risk and the persistence of this excess weight after pregnancy, she is exposed to obstetric complications during childbirth, high risk of fetal macrosomia, shoulder dystocia and cesarean delivery. In 1990 and 2009, the Institute of Medicine (IOM) proposed recommendations for optimal weight gain during pregnancy [4]. They are conditioned by the starting weight, with a minimum weight gain of $7 \mathrm{~kg}$ and a maximum weight gain of 18 kgs [5] [6]. This issue of weight gain during pregnancy has been the subject of several Western studies. Zonana-Nacach, Mexico, found excessive weight gain in $38 \%$ of pregnant women; this rate is higher for Park, Crane and Chung, who report rates of $51 \%$ in the United States, $52 \%$ in Canada and $74 \%$ in Great Britain [7] [8] respectively. In Africa, a study conducted in Ghana by Abubakarir shows that $7.40 \%$ of pregnant women have excessive weight gain [9]. In Yaounde, a 2014 study at the Gyneco-Obstetrics Hospital 42.7\% of women had an excessive weight gain in a population having delivered by cesarean section [10] [11]. In the city of Douala there are no data on excessive weight gain in pregnancy and its consequences. It is with the aim of sensitizing the pregnant women and to prevent the possible consequences related to this phenomenon we proposed ourselves to realize this study in a hospital structure with large affluence: the hospital Laquintinie of Douala (HLD).

\section{Methods}

This study was an analytical cross-sectional study conducted at Laquintinie Hospital in Douala over a period of about 3 months; from February to May 2017. For the sample size calculation, we used the formula of Schulz and Grimes [12]: $n=\left[10.51\left[(R+1)-P 2\left(R^{2}+1\right)\right] / P 2(1-R)^{2}(n=\right.$ the sample size in each of the groups, $p 1=$ event rate in the treatment group (not in formula but, implied when $R$ and $P 2$ are estimated)). $P 2=$ event rate in the control group, $R=$ risk ratio $(P 1 / P 2)$. In our study, we chose as a criterion of judgment the rate of caesarean section in women which is $18.64 \%$ in a study made in Yaoundé in 
2015 [13]. So, the value of $P 2=0.1864$. By estimating that excessive weight gain during pregnancy would double this rate by two, we obtain a value $P 1=0.3728$ and the value of $R=2$. After digital application, we obtained a minimum sample size $n=116$ pregnant for each group. All pregnant women in labor in the maternity ward were included except for those with multiple pregnancy, scarred uterus, malformation of the pelvis and those who started antenatal visits after 16 weeks of amenorrhea. Two groups were then formed, one having an excessive weight gain during pregnancy and the other having none. This distribution was made using the IOM weight gain recommendation table. Information on anthropometric, sociodemographic, medical and gynecological obstetrical history, childbirth and newborn outcomes was collected through a standardized questionnaire. Pregnant women were seen and interviewed between the lulls of labor for some and postpartum or caesarean for others when their consent obtained. It was noted in their prenatal checkbooks the weight before the 16th SA as well as the weight in the third trimester which allowed us to obtain the total weight gain by making the difference between the weights at the end and at the beginning of the pregnancy. The height was noted on their national identity cards and the rest of the information in the medical file. Statistical analyzes were done by SPSS software version 20.0. The search for associated factors was performed using the logistic regression method in uni and multivariate analysis. Odds Ratio (OR) and Relative Risk (RR) were used to measure the degree of association. The threshold of significance was set at a value $\mathrm{p}<0.05$.

\section{Results}

During our study period, we found 282 pregnant women in labor, after looking for exclusion criteria 240 were selected, 59 with excessive weight gain, a prevalence of 24.6\% $(\mathrm{N}=240)$ (Table 1). Pregnant women with a BMI $>30 \mathrm{~kg} / \mathrm{m}^{2}$ before 16 weeks had a statistically significant risk of excessive weight gain during pregnancy $(\mathrm{OR}=2.40, \mathrm{CI} 1.3-4.5, \mathrm{P}=0.004)($ Table 2$)$.

Sociodemographic data: Sociodemographic variables analyzed, as shown in Table 3, only married marital status was a factor in excess weight gain in pregnancy $(\mathrm{OR}=2.0, \mathrm{CI}: 1.1-3.8, \mathrm{P}=0.026)$.

Maternal complications during labor and post-partum: Regarding the uterine height, the average in the exposed was 35.4 against 34.03 in the unexposed with a significant difference $(\mathrm{P}=0.007)$.

Complications during labor and in post-partum: Concerning the pathologies that occurred during the pregnancy, the pregnancy-related HTA was found in exposed to $3.4 \%$ with a difference close to the significance (Table 4). Malaria was the most common pathology with $11.9 \%$ in the exposed and $5.0 \%$ in the unexposed. It is important to point out that none of our patients had gestational diabetes.

Fetal Complications: Regarding the weight of neonates, the average exposure was 3472 compared to 3306 in unexposed patients with a significant difference (Table 5). 
Table 1. Prevalence of excessive weight gain in pregnancy.

\begin{tabular}{ccc}
\hline BMI before 16 WA & Exposed & Not exposed \\
\hline$<18.5$ & $1(20.0)$ & $4(80.0)$ \\
{$[18-25[$} & $15(15.3)$ & $83(84.7)$ \\
{$[25-30[$} & $18(25.7)$ & $52(74.3)$ \\
$\geq 30$ & $25(37.3)$ & $42(62.7)$ \\
All the population & $59(24.6)$ & $181(75.4)$ \\
\hline
\end{tabular}

WA: Week of Amenorrhea.

Table 2. Breakdown of exposure by BMI before 16 WA.

\begin{tabular}{ccccc}
\hline IMC avant 16 WA & $\begin{array}{c}\text { Exposed } \\
\mathbf{N}=\mathbf{5 9} \\
\mathbf{n}(\%)\end{array}$ & $\begin{array}{c}\text { Not exposed } \\
\mathbf{N}=\mathbf{1 8 1} \\
\mathbf{n}(\%)\end{array}$ & OR (IC 95\%) & P-value \\
\hline$<18.5$ & $1(1.7)$ & $4(2.2)$ & $0.8(0.1-6.9)$ & 0.810 \\
{$[18-25[$} & $15(25.4)$ & $83(45.9)$ & $0.4(0.2-0.8)$ & 0.006 \\
{$[25-30[$} & $18(30.5)$ & $52(28.7)$ & $1.1(0.6-2.1)$ & 0.794 \\
$\geq 30$ & $25(42.4)$ & $42(23.2)$ & $2.4(1.3-4.5)$ & 0.004 \\
\hline
\end{tabular}

Table 3. Distribution of exposed and unexposed by marital status, occupational status.

\begin{tabular}{|c|c|c|c|c|}
\hline Variables & $\begin{array}{c}\text { Exposed } \\
\mathrm{N}=59 \\
\mathrm{n}(\%)\end{array}$ & $\begin{array}{l}\text { Non exposed } \\
\qquad \begin{array}{c}\mathrm{N}=181 \\
\mathrm{n}(\%)\end{array}\end{array}$ & OR (IC à 95\%) & P-value \\
\hline \multicolumn{5}{|l|}{ Marital status } \\
\hline Married & $22(37.3)$ & $41(22.7)$ & $2.0(1.1-3.8)$ & 0.026 \\
\hline Single & $37(62.7)$ & $140(77.3)$ & & \\
\hline \multicolumn{5}{|l|}{ Professional status } \\
\hline Official & $4(6.8)$ & $9(5)$ & $1.4(0.4-4.7)$ & 0.528 \\
\hline Private sector employee & $7(11.9)$ & $25(13.8)$ & $0.8(0.3-2.1)$ & 0.827 \\
\hline Self-employment & $17(28.8)$ & $53(29.3)$ & $0.9(0.5-1.9)$ & 0.999 \\
\hline Student & $21(35.6)$ & $43(23.8)$ & $1.8(0.9-3.3)$ & 0.074 \\
\hline Unemployed & $10(16.9)$ & $51(28.2)$ & $0.5(0.2-1.1)$ & 0.085 \\
\hline
\end{tabular}

Table 4. Distribution according to pathologies occurring in pregnancy.

\begin{tabular}{ccccc}
\hline Pathologies on pregnancy & $\begin{array}{c}\text { Exposed } \\
\mathbf{N = 5 9} \\
\mathbf{n}(\%)\end{array}$ & $\begin{array}{c}\text { Not exposed } \\
\mathbf{N}=\mathbf{1 8 1} \\
\mathbf{n}(\%)\end{array}$ & $\begin{array}{c}\text { RR } \\
(\mathrm{IC}=95 \%)\end{array}$ & P-value \\
\hline HTA $^{1}$ & $2(3.4)$ & $0(0.0)$ & $/$ & 0.063 \\
VIH $^{2}$ & $0(0.0)$ & $6(3.3)$ & $/$ & 0.333 \\
Malaria & $7(11.9)$ & $9(5.0)$ & $1.9(1.03-3.4)$ & 0.076 \\
UI $^{3}$ & $0(0.0)$ & $1(0.6)$ & $/$ & 0.978 \\
IST $^{4}$ & $2(3.4)$ & $1(0.6)$ & $2.8(0.4-6.4)$ & 0.268 \\
PCT $^{5}$ & $2(3.4)$ & $9(5.0)$ & $0.7(0.2-2.6)$ & 0.936 \\
\hline
\end{tabular}

HTA $^{1}$ : Hypertension; HIV ${ }^{2}$ : Human Immunodeficiency Virus; UI³ : Urinary infection; STI ${ }^{4}$ : Sexually Transmitted Infection; PCT $^{5}$ : Premature Childbirth Threat. 
Table 5. Distribution of exposed and unexposed by birth weight of newborns.

\begin{tabular}{ccccc}
\hline Weight at birth & $\begin{array}{c}\text { Exposed } \\
\mathbf{N = 5 9} \\
\mathbf{n}(\%)\end{array}$ & $\begin{array}{c}\text { Not exposed } \\
\mathbf{N}=\mathbf{1 8 1} \\
\mathbf{n}(\%)\end{array}$ & $\begin{array}{c}\text { RR } \\
(\text { IC = 95\%) }\end{array}$ & P-value \\
\hline$<4000$ & $50(84.7)$ & $165(91.2)$ & $0.6(0.4-1.2)$ & 0.161 \\
$\geq 4000$ & $9(15.3)$ & $16(8.8)$ & & \\
Moyenne \pm ET & $3472 \pm 580.8$ & $3306 \pm 461.9$ & & 0.023 \\
Min - Max & $2100-5500$ & $1800-4550$ & & \\
\hline
\end{tabular}

\section{Discussion}

In our study, we recorded a total of 240 pregnant women, 59 of whom were overweight during pregnancy (exposed), or $24.6 \%$ of the total pregnant population.

This result differs from the $42.7 \%$ found by Foumane et al. in a study conducted at the Gyneco-Obstetrics Hospital of Yaounde on a population of pregnant women who had given birth by caesarean section [11]. In Ghana, Abubakari et al. found that $7 \%$ of pregnant women had excessive weight gain during pregnancy [9].

Among the exposed, we found women with all classes of BMI, nevertheless we were able to highlight the frequency of pre-gestational obesity which was $42.4 \%$. N'Guessan et al. report a frequency of pre-gestational obesity at 11.3\% [14]. This percentage differs from the $16 \%$ found by Ahoukeng at the Gyneco-Obstetrics and Pediatric Hospital of Yaoundé and the 7.5\% found by Ducarme [15] [16].

The socio-demographic data studied were age, marital status, region of origin, employment status, level of education, area of residence and type of neighborhood. Only marital status was significantly associated (OR: 2.0; 95\%; CI $=1.1$ $3.8 ; \mathrm{P}=0.026)$. The exposed were $37.3 \%$ married with a statistically significant difference. This result is consistent with that of Mochhoury et al. in Morocco, who found that $38 \%$ of pregnant pregnancies had excessive weight gain during pregnancy [17].

This can be explained by the fact that the status of married women brings a psychological balance and a higher number of pregnancies, which can lead to excessive weight gain during pregnancy.

Maternal complications associated with excessive weight gain during pregnancy were elevated blood pressure at delivery, onset of labor, maternal complications during labor and postpartum, hours of labor, mode of delivery. Only the uterine height had a higher average in the exposed 35.4 versus 34.03 in the unexposed ones.

The occurrence of gestational hypertension in exposed patients had a difference that was close to the significance $(\mathrm{P}=0.063)$.

In the exposed, $3.4 \%$ were found with pregnancy-related HTA versus $0.0 \%$ in the unexposed with a difference close to the significance $(\mathrm{P}=0.06)$. This joins Grossetti et al., who found with a statistically significant difference the presence 
of HTA $7.7 \%$ in unexposed patients versus $0.5 \%$ in exposed patients [18]. This could be explained by the fact that pregnancy-related HTA is a maternal complication associated with excessive weight gain during pregnancy.

In our data we had caesarian section in $32.2 \%$ in exposed patients versus $21.5 \%$ in unexposed patients, although the difference was not significant. In 2014, Foumane et al. conducted a study on excessive weight gain in pregnancy and the outcome of delivery to the Gyneco-Obstetrics and Pediatric Hospital of Yaounde on a population of pregnant women having delivered by caesarean section where they found $42.7 \%$ exposed against $57.3 \%$ unexposed [11].

These results are in stark contrast to most other data in the literature that have shown with significant difference that excessive weight gain in pregnancy is a risk factor for caesarean delivery [11] [15] [19]. N'Guessan, meanwhile, found the mode of cesarean delivery in equal proportion in both groups of pregnant [14].

In our study, we had a mean uterine height in the exposed of 35.4 versus an average of 34.03 in the unexposed with a statistically significant difference. Mouchhoury reports a significant difference between exposures with greater uterine height than unexposed ones [17]. The presence of a large adipose tissue in the exposed can lengthen the uterine height which would explain this difference.

The fetal complications associated with excessive weight gain during pregnancy were fetal presentation, fetal complications during labor, birth defects, Apgar score in the 1st and 5th minute, and weight of birth. Only the mean birth weight in neonates exposed was significant $(\mathrm{P}=0.023)$. Our results are in line with those of the other studies with a weight average of $3472 \mathrm{~g}$ exposed compared with $3306 \mathrm{~g}$ of unexposed patients with a statistically significant difference $(\mathrm{P}=0.023)$.

The literature data unanimously and significantly show a higher mean weight in neonates exposed [11] [15] [17] [20] [21].

Abrams et al. showed that there was a linear relationship between birth weight and maternal weight gain with a slope that was greater as the weight was normal before pregnancy. The mechanisms of this phenomenon are still poorly understood. Glucose is one of the most important substrates of energy metabolism and fetal growth. There is also a linear relationship between maternal glucose and glucose umbilical flow, thus fetal blood glucose [21].

This would support the hypothesis that excess maternal weight gain would promote fetal growth via increased blood glucose. Two elements, however, contradict this hypothesis. On the one hand, excess maternal weight gain does not appear to be related to the onset of gestational diabetes [21] [22] [23], and this is rather influenced by pre-existing obesity or rapid weight gain before or at the beginning of pregnancy [24].

Several limitations are identified in our study such as its single center cohort. Most of our patients were of African descent and this might skew the findings. This study presents novel data from Cameroon, but the sample size is relatively 
small compared to similar series from other countries.

\section{Conclusions}

Excessive weight gain during pregnancy is responsible for a significant increase in the risk of onset of gestational hypertension, uterine height, and mean birth weight of newborns.

Recommendations for optimal weight gain during pregnancy have been documented and reported by WHO. They are conditioned by the starting weight, with a minimum weight gain of $7 \mathrm{~kg}$ and a maximum weight gain of $18 \mathrm{kgs}$. Several studies have been done on the subject in different parts of the world and their data are known.

None on the subject has been made in the Cameroonian economic capital. Our study adds to the data by showing that $24.6 \%$ of pregnant women had an excessive weight, that pregnant women who had maternal complications associated with excessive weighting had on average a high uterine height 35.4; the occurrence of gestational hypertension showed differences that were close to the significance and the mean birth weight was higher in those with excessive weight gain.

\section{Conflicts of Interest}

The authors declare no conflict of interest.

\section{Contributions of the Authors}

Dr. Bewekedi collected the data; Dr. Essome and wrote the article; Dr. Engbang, Boten, Ekono and Mve corrected the article; Foumane supervised and co-ordinated the redaction.

\section{References}

[1] Hytten, F.E. and Leitch, I. (1971) The Physiology of Human Pregnancy. 2nd Edition, Blackwell Scientific Publications, Oxford.

[2] Hickey, C.A., Cliver, S.P., McNeal, S.F., Hoffman, H.J. and Goldenberg, R.L. (1996) Prenatal Weight Gain Patterns and Birth Weight among Non Obese Black and White Women. Obstetrics \& Gynecology, 88, 490-496. https://doi.org/10.1016/0029-7844(96)00262-1

[3] WHO (1998) Obesity: Preventing and Managing the Global Epidemic. Working Group on Obesity. World Health Organization, Geneva.

[4] Institute of Medicine. Committee on Nutritional Status during Pregnancy and Lactation (1990) Nutrition during Pregnancy. Part I, Weight Gain. National Academy Press, Washington DC.

[5] Institute of Medicine (2009) Weight Gain during Pregnancy: Reexamining the Guidelines. National Academy Press, Washington DC.

[6] Siega-Riz, A.M., Viswanathan, M. and Moos, M.K. (2009) A Systematic Review of Outcomes of Maternal Weight Gain According to the Institute of Medicine Recommendations: Birthweight, Fetal Growth, and Postpartum Weight Retention. American Journal of Obstetrics and Gynecology, 339, e1-14. 
[7] Crane, J.M.G., White, J., Murphy, P., Burrage, L. and Hutchens, D. (2009) The Effect of Gestational Weight Gain by Body Mass Index on Maternal and Neonatal Outcomes. Journal of Obstetrics and Gynaecology Canada, 31, 28-35. https://doi.org/10.1016/S1701-2163(16)34050-6

[8] Chung, J.G., Taylor, R.S., Thompson, J.M., Anderson, N.H., Dekker, G.A., Kenny, L.C. and McCowan, L.M. (2013) SCOPE Consortium. Gestational Weight Gain and Adverse Pregnancy Outcomes in a Nulliparous Cohort. European Journal of Obstetrics \& Gynecology and Reproductive Biology, 167, 149-153. https://doi.org/10.1016/j.ejogrb.2012.11.020

[9] Abubakari, A., Kynast-Wolf, A. and Jahn, A.J. (2015) Maternals Determinants of Birth Weight in Northern Ghana. PLoS ONE, 10, 130-140.

[10] Cameroun Enquête démographique et de santé (2017) Allaitement maternel, état nutritionnel des enfants et des femmes. 2004: 207-9. Disponible à. http://www.measuredhs.com/pubs/pdf/FR163/FR163-CM04.pdf

[11] Foumane, P., Mando, E., Dobbit, J., Dogbina, W. and ZeMinkande, J. (2014) Outcome Cesarean Delivery in Woman with Excessive Weight Gain during Pregnancy. Open Journal of Obstetrics and Gynecology, 4, 139-143. https://doi.org/10.4236/ojog.2014.43024

[12] Schulz, K.F. and Grimes, D.A. (2005) Sample Size Calculations in Randomized Trials: Mandatory and Mystical. Lancet, 365, 1348-1353. https://doi.org/10.1016/S0140-6736(05)61034-3

[13] Ngowa, J.D., Ngassam, A., Fouogue, J.T., Metogo, J., Medou, A. and Kasia, J.M. (2015) Early Maternal Complications of Cesarean Section: About 460 Cases in Two University Hospitals in Yaounde, Cameroon. Pan African Medical Journal, 21, 265.

[14] N'guessan, K., Knabben, L., Abauleth, R., Angoi, V., Nigue, L. and Boni, S. (2008) Obésité et grossesse: Une expérience africaine concernant 506 patientes. La Lettre du gynécologue, 328-329, 6-9.

[15] Ahoukeng, P., Mboudou, T.E., Foumane, P., Dohbit, J., Tiomela, P. and Nnang, M.G. (2015) Issue maternofoetale de la grossesse chez la femme obèse à l'hopital gynéco-obstétrique et pédiatrique de Yaoundé, Cameroun. Revue de Médecine Périnatale, 7, 110-116. https://doi.org/10.1007/s12611-015-0306-Z

[16] Ducarme, G., Roocrigues, A., Aissaoui, A., Davitian, C., Pharisian, I. and Uzan, M. (2007) Grossesse des patientes obèses: Quels risques faut-il craindre? Gynécologie Obstétrique \& Fertilité, 35, 19-24.

[17] Mouchhoury, L., Razine, R., Kharbach, A. and Barkat, A. (2013) Prise pondérale maternelle pendant la grossesse et poids des nouveaux-nés. Données marocaines. Revue Medicale de Bruxelles, 5, 111-119. https://doi.org/10.1007/s12611-013-0234-8

[18] Hamon, C., Fanello, S., Catala, L. and Parot, E. (2005) Conséquences de l'obésité maternelle sur le déroulement du travail et l'accouchement: À l'exclusion des autres pathologies pouvant modifier la prise en charge obstétricale. Journal of Gynecology Obstetrics and Human Reproduction, 34, 109-114. https://doi.org/10.1016/S0368-2315(05)82702-4

[19] Grossetti, E., Beucher, G., Regeasse, A., Lamendour, N., Helicoviez, M. and Dreyfus, M. (2004) Complications obstétricales de l'obésité morbide. Journal de Gynécologie Obstétrique et Biologie de la Reproduction, 33, 739-744. https://doi.org/10.1016/S0368-2315(04)96636-7

[20] Deruelle, P., Houfflin-Debarge, V., Vaast, V., Delville, N., Hélou, N. and Subtil, D. (2004) Effets maternels et foetaux d'une prise de poids maternelle excessive au cours de la grossesse dans une population de patientes de poids normalavant la grossesse. 
Gynécologie Obstétrique \& Fertilité, 32, 398-403.

https://doi.org/10.1016/j.gyobfe.2004.02.018

[21] Hay Jr., W.W., Sparks, J.W., Quissell, B.J., Battaglia, F.C. and Meschia, G. (1981) Simultaneous Measurements of Umbilical Uptake, Fetal Utilization Rate, and Fetal Turnover Rate of Glucose. American Journal of Physiology, 240, E662-E668.

[22] Edwards, L.E., Hellerstedt, W.L., Alton, I.R., Story, M. and Himes, J.H. (1996) Pregnancy Complications and Birth Outcomes in Obese and Normal-Weight Women: Effects of Gestational Weight Change. Obstetrics \& Gynecology, 87, 389-394. https://doi.org/10.1016/0029-7844(95)00446-7

[23] Shepard, M.J., Hellenbrand, K.G. and Bracken, M.B. (1986) Proportional Weight Gain and Complications of Pregnancy, Labor, and Delivery in Healthy Women of Normal Prepregnant Stature. American Journal of Obstetrics \& Gynecology, 155, 947-954. https://doi.org/10.1016/0002-9378(86)90323-6

[24] Solomon, C.G., Willett, W.C., Carey, V.J., Rich-Edwards, J., Hunter, D.J., Colditz, G.A., et al. (1997) A Prospective Study of Pregravid Determinants of Gestational Diabetes Mellitus. JAMA, 278, 1078-1083.

https://doi.org/10.1001/jama.1997.03550130052036 